\title{
STRATEGIC PLAN OF DEVELOPMENT OF TOURISM IN BINTAN REGENCY
}

\author{
Zamzami A. Karim \\ Lecturer of Government Science Department \\ Raja Haji School of Social and Political Science \\ Tanjungpinang, Kepulauan Riau Provience \\ e-mail: zamikareem@gmail.com
}

Faizal Rianto

Lecturer of Public Administration Science Department

Raja Haji School of Social and Political Science

Tanjungpinang, Kepulauan Riau Provience

faizalrianto@gmail.com

\begin{abstract}
Bintan Regency is one of the National Tourism Destination (DPN) which is in a very strategic position. As a strategic area, Bintan also has a National Strategic Tourism Area (KSPN) that is Lagoi. However, further development is needed, so that Bintan Regency can rely on tourism sector as a sustainable source of income for the region. It needs strategic planning also in the development of long-term tourism. This research can find a strategic plan in developing tourism in Bintan regency. Methods in collecting data used Field observation methods (survey), interviews, literature studies, studies of regulations and related legislation and methods in the analysis using the SWOT method. The result of the research is the strategic plan in developing tourism in Bintan Regency. And the results of the research will be a recommendation in building tourism in Bintan regency
\end{abstract}

\section{Keywords - Strategic Plan, Development, Tourism}

\section{INTRODUCTION}

Tourism as a sector has taken an important role in economic development. Higher progress and prosperity has made tourism a central part of human needs or lifestyle, and drives millions of people to know nature and culture to parts of the world. The movement of millions of humans further drives the linked linkages of economic linkages into a service industry that makes an important contribution to the economy, as well as improving economic prosperity at the local community level.

In the history of development in Indonesia, the strategic role of tourism in contributing the acquisition of foreign exchange, regional income (PDRB), and increasing the welfare of the community mainly through; the absorption of manpower, the increase of income and the growth of the business field is no longer undeniable existence. Data trends from the past five years have provided significant evidence of performance improvements in the tourism sectors.

The success of the tourism sector to be able to become one of the leading sectors in a region in dire need of appropriate and appropriate management with the characteristics of the region. Because management in

\author{
Suherry \\ Lecturer of Government Science Department \\ Raja Haji School of Social and Political Science \\ Tanjungpinang, Kepulauan Riau Provience \\ e-mail: suherry89@mail.com
}

developing the tourist area must be interconnected and support between sectors.

Therefore, the development of Bintan Regency is expected to provide a balance of tourism growth in Indonesia, and make this area as one of the growth poles of tourism development in the West Indonesia. Furthermore, efforts to develop tourism destinations as a major element of tourist attraction to Indonesia need to be systematically implemented, with the support of development of marketing, development and a reliable tourism industry to strengthen the development of existing tourism destinations.

\section{A. Tourism}

\section{LITERATURE REVIEW}

The term tourism is born from Sanskrit whose components consist of: "Pari" meaning full, complete, traveling; "Wis (man)" which means house, property, village, community; and "ata" means to go on and on, roaming about, which when assembled into one word gave birth to the term tourism, means: to go completely leave home (kampung) to go around continuously and not intend to settle in the destination Pendet in Lombote, 2015). According to Pitana (2009: 14) Tourism is an activity to travel with the aim of gaining pleasure, seeking satisfaction, knowing something, health, enjoy sports or rest, adjust tasks, etc., is not an activity recently conducted by, humans present time.

According to Law Number 10 Year 2009 on Tourism, it is explained about the definition or definition as: Overall tourism-related and multidimensional and multidisciplinary activities that arise as a manifestation of the needs of every person and country and the interaction between tourists and the local community, fellow travelers, the Government, Local Government and entrepreneurs.

In a variety of tourism, according to Sunaryo (2013: 3) tourists are people or groups of people who travel for tourism purposes, such as to be creative, doing business or to meet other special needs. 
From the state sharing can be empirically proven that the number of tourist visits (number of tourist), length of stay in the destination (length of stay) and spending money (Money spending) and the number of movements of domestic tourists in a country, in addition will be able to become, the source of Foreign exchange gains, also functions as an instrument of equitable distribution of development, growing various business fields and employment absorption associated with tourism or as a motor to increase income.

Tourism has been proven to encourage economic growth through investment, employment opportunities, business opportunities, and ultimately can improve the welfare of the community. Business opportunities open only in the form of development of tourism facilities and infrastructure but also in the field of craft.

The concept of tourism according to Burkart and Medlik (Lombote, 2015). Travelers have four characteristics, among them are:

a. Tourists are people who travel and live in various places aim.

b. Tourist destinations are different from where they live and work everyday, so the activities of tourists are not the same as the activities of residents who live and work in tourist destinations.

c. Tourists intend to return home in a few days or months-monthly, because the journey is temporary and long-term.

d. Tourists do not travel to find a place to stay for settle at the destination or work to earn a living.

\section{B. Tourism Development Strategy}

Development in principle is a:. ... the process of fundamental change in society from a certain national state to another national state which is considered more valuable ... (Katz in Sunaryo, 129: 2013). In another sense according to Philip Roup (Sunaryo, 129: 2013) defines development as: ... a process of change with signs of a certain national situation which is deemed to be less desirable towards something national circumstance which is considered more desirable ...

If the understanding of the above understanding of development is applied to tourism becomes; a process of fundamental change undertaken by humans on a less favorable tourism condition directed towards a particular tourism condition that is considered better or more desirable. (Surnaryo, 129: 2013).

In the context of development planning of tourism is quite actively moving to know the meaning of goals and strategies to achieve a condition of tourism that is considered better and more valuable. For that agreed an alternative model and strategy in tourism development planning that has been developed and applied is also considered good.

The four rules that should underlie a model and tourism development planning strategy, are:

1. Preferences to certain vision, mission, objectives and priority goals of tourism development process to be held. The entire vision, mission, objectives and objectives documents are usually formulated by the political will of the competent authorities

2. Adaptive flexibility of the growth of tourism development in accordance with the dynamics of social, economic, cultural and political developments in both national and international levels.

3. Maintaining the sustainability of tourism development that has included anticipation for demands for future generations.

4. Anticipation and responsiveness in which tourism development planning must always consider, take into account, and take into account the overall dynamics of the situation and the reality of tourism reality throughout the region concerned.

Along with the demands and the escalation of needs change, the shifting mindset of the world community, and the dynamics of the development of strategic issues that will affect the development of tourism, it has finally developed at least 3 variants of the strategy of tourism development planning model which is often used as the basic reference by tourism development planners . The three tourism development planning strategies are:

1. Tourism development planning strategies that prioritize on growth (growth oriented model)

2. Strategy of tourism development planning that is based on community empowerment (communitybased tourism development)

3. Strategy of tourism development planning which is based on sustainable tourism development (sustainable tourism development)

Furthermore, theoretical can be said (inskeep, 1991); tourism development planning is a process to prepare systematically and rationally all tourism activities or activities that will be carried out to achieve these objectives optimally by allocating all available resources effectively and efficiently.

In much of the understanding of tourism development planning (BTA 1996, Gunn and Clare 1994), tourism planning can also be defined as: a prediction and future projection through consideration of the situational and experiential analysis that exists in declaring the tourism objectives to be realized.

Planning is one of the management functions that have a very important role and determine the smoothness and success of development. In this connection, careful planning, proper implementation, and optimal supervision is the key to realizing development goals including the development of tourism.

Things to consider in developing tourism development planning is a consideration that the implementation of the tourism development program to be carried out will greatly affect the existence of the most fundamental values of private life, family, community, and nation widely. Therefore, the preparation of tourism development planning should be done carefully, deeply, and thoroughly and precisely anticipate the overall circumstances that will occur in the future. 
The determination of a tourism development planning becomes very important to always be considered because the planning of tourism development will always encountered the potential, problems, challenges and opportunities faced simultaneously. At the stage of situation analysis in developing tourism development planning will be encountered many challenges both coming from within and factors that come from outside, as well as opportunities and strategies utilized in order to achieve goals that have been set optimally.

\section{DISCUSSION}

\section{A. STRATEGIC ISSUES}

\section{Tourism Destination}

Bintan is the island's largest island in Riau Islands Province. In accordance with Government Regulation No. 5 of 2006, Bintan Island was established as Bintan Regency since 23 February 2006. Geographically, Bintan Regency is located in a strategic position. Berintan also borders directly with neighboring countries namely Singapore and Malaysia.

From the beginning, Bintan was projected as a tourist and rest island. Beautiful beaches that have been decorated with many classy facilities mostly located along the island's north coast, precisely in the area of Lagoi. Lagoi is selected as a beach resort because it has a beach that has calm for most of the year and faces directly with Singapore and Malaysia. The attractions in this area are the Exclusive Integrated Tourism Area Lagoi (Bintan Resort), Sebong Pereh Tourism Village which offers marine tourism, and Sebong Pereh Beach. In this area there are various tourist facilities as well as the jet set, among others, several star hotels, bars and discos, luxurious spa, as well as several golf courses.

Not only the Lagoi area, Bintan Island also provides other tourist attractions ranging from nature tourism, ecological tourism, cultural tourism, and historical tours. Tanjung Berakit Beach, Trikora Beach and Kawal Fishermen's Village, the beaches of Pulau Kecil in Bintan Island and Bintan Leisure Park, and Bintan Mountain Fountain, Mount Bintan Cave, and Lake Galian Belt in Teluk Bintan Sub-district can be provides an alternative tourist spot that is not less beautiful with the Lagoi area. Ecological tourism can be done by visiting and participate in planting trees in mangrove forests along the east coast of Bintan Island and protected forests

With the right positioning for tourism development in Bintan, Bintan can become a tourism alternative for regional tourists. Offering different attractions with Singapore and Malaysia will certainly add to the choice of tourists who are interested in visiting not only Singapore and Malaysia, but certainly visiting Bintan. But to develop better tourism in the future, it can be seen there are several strategic issues in the development of tourism destinations, among others: a) Arranging synergistic tourism zoning with strategic potential and other related sectors development still needs to be re-organized

b) Bintan tourism attraction is still dominated by the pattern of development of resort / marine tourism, development of tourism based on culture still need to be developed (art, culinary, handicraft)

c) Bintan tourism image perceived as a safe and comfortable and family oriented destination still needs to be improved and strengthened through development of attraction, landscape arrangement, development of facilities and adequate infrastructure.

d) The strategic potentials of tourism that have not yet appeared and still need to be elaborated and further developed (diving, snorkeling, fishing, deepsea fishing, culinary, heritage, mangrove, village).

e) Bintan community empowerment that still needs to be improved, especially the awareness of the local community will benefit the development of tourism.

f) Development of an investment climate that still needs to be improved, especially about the ease of regulation and investment security.

\section{Tourism Marketing}

Market phenomenon can not be separated from various internal issues. The various trends that occur in the market will have a direct and indirect impact on changing market tastes. Likewise with Bintan, as a destination also has some tendencies that are similar to some other areas in Indonesia related to tourism marketing issues. The following are some of the most common and specific issues related to tourism in Bintan and surrounding areas:

a) Tourist arrivals to Bintan are dominated by foreign tourists $(80 \%)$ in comparison with the domestic market (20\%), which is suspected to be influenced by geographic proximity.It is heavily influenced by the characteristics of available products and geographical proximity between Bintan and neighboring countries (Singapore) which is indicated by the dominance of the Singapore market for the tourist market groups in Bintan.

b) Stagnation of Tourist Market Growth: the growth of the tourism market in Bintan is also relatively low (tends to be stagnant)

c) Short length of stay: the average tourist just stop over no more than 2 days, the variety of attractions and the proximity of the position of Bintan with Singapore (as the majority segment) may be a factor of low duration of stay because it is only

d) The effectiveness of branding Bintan tourism (breathtaking journey) because not yet widely known by the market

e) Potential market diversification outside Singapore market is still potential to be developed (China, South Korea, Japan) as well as domestic market

f) As a world-class tourism destination, the image / image of Bintan tourism needs to be strengthened so 
as to compete with Batam as an alternative tourism destination that has a superior character

g) The need for marketing institutions that will strengthen Bintan tourism promotion efforts

h) Diversification in the use of promotional media that increasingly understand the preferences of tourists including the use of modern communication media and social media, and not limited to sport tourism event but also towards the potential of local culture.

\section{Tourism Industry}

The tourism business partnership in Bintan still has not been seen running maximally. The tourism industry in Bintan still seems to run on its own, yet shows no cooperation between one another. Therefore, the pattern of partnerships between tourism businesses, as well as tourism businesses with other business actors in Bintan still need to be improved. Forms of partnership that can be done, for example cooperation in the development of tourist attraction, promotion and marketing cooperation, The following strategic issues in the development of the tourism industry, among others:

a) Strengthening of tourism business such as: exploitation of attractiveness, accommodation, transportation services, travel services, entertainment services, and others still need to be improved

b) Pattern of tourism business partnership, whether between tourism business, tourism business actors with other business actors, and tourism business actors with the community, still need to be improved

c) The potential of local resources, such as agricultural products, livestock, fishery, handicrafts, arts, etc. have not been fully utilized by the tourism industry

d) The quality and competitiveness of tourism products still require improvement to support its position as an international destination

\section{Tourism Institutions}

Tourism is a sector that has a high intensity of relationships and linkages with other sectors or sectors both cross-sectoral and cross-regional (cantonal). Relationships in cross-sectoral contexts, among others related to the forestry sector, marine, agriculture and plantation, industry and trade, telecommunications, transportation, kimpraswil, environment, culture, education, immigration and foreign affairs, and other related sectors or fields. These relationships include aspects of resource utilization, infrastructure and infrastructure support, human resource support, policy support ease of licensing, investment, and other forms of regulation. The following are strategic issues in the development of tourism institutionalization, among others:

a) The role of society as a good tourism host still needs to be empowered and enhanced

b) Tourism becomes the mainstay sector and the largest PDRB support for Bintan, so that organizations / institutions and institutions related to tourism management need to be strengthened and enhanced their qualifications and quality

c) Tourism becomes the mainstay sector and the largest PDRB support for Bintan, so that its human resources need to be strengthened and improved its qualification and quality

d) Regulations governing the management of tourism still need to be strengthened

e) Synergies and coordination across sectors and crossplayers in the development of tourism is still necessary

\section{B. STRATEGIC PLANNING TOURISM}

This section describes in detail the direction of policies, strategies and indications of programs that support tourism development in Bintan regency. All programs of activities within the pillars of tourism development are aimed at realizing Bintan's vision, mission, goals and objectives of tourism development. In the table below will be presented Policy Direction, Strategy and Indication of Tourism Development Program of Bintan Regency

\section{Tourism Destination}

a) The territorial division of tourism

The development of thematic tourist spaces in a synergic, complementary and integrated arrangement of relations to enhance the verified tourism products and competitiveness of Bintan tourism. Comprehensive travel experience for tourists on tourism products can be created through the establishment of thematic zones developed from the potential and uniqueness of each locality or potential tourist area in Bintan Regency, which is integrated in an integrated manner so that it has different / varied attractions from one area to another.

The development of zones with thematic products will create an alternative choice of visits for tourists, so it is expected to encourage the growth and development of existing sub-sub-region with specific tourism products, increase the length of stay and encourage the growth and development of diverse tourism business opportunities for the local community / around it. The direction of development policy mentioned above will be realized through strategy:

a) Arranging the development plan of Tourism Spaces / Sub Area of Thematically integrated Tourism as area of tourism development area (KPPD) in Regency of Bintan.

b) Prepare management plan and regulation of development of regional tourism development area (KPPD)

Based on the characteristics of tourism objects and potentials in Bintan regency, the development of thematic tourist spaces, among others, includes:

a) Development of cluster / KPPD LAGOI dskt (which is based on natural tourist attraction - sea pantaidan as enclave integrated coastal resort) 
b) Cluster development / KPPD TRIKORA - BERKIT dskt (based on tourism attraction - natural beach / maritime / marine tourism)

c) Development of cluster / KPPD KORINDO dskt (based on natural tourist attraction - agro / agro tourism)

d) Development of cluster / KPPD NIKOI - MAPUR dskt (marine tourism attraction - islands / island tourism)

e) Development of cluster / KPPD TAMBELAN dskt (natural tourist attraction - bahari - islands / island tourism)

f) Cluster development / KPPD KIJANG - LICIN STONE dskt (cultural attraction - history and custom of local tradition / culture and heritage tourism)

g) Cluster development / KPPD MOUNTAIN BINTAN dskt (cultural attraction of natural heritage - forest of mountains / ecotourism)

h) Development of cluster / KPPD TANJUNG UBAN Lobbing dskt (which is based on special tourist attraction - industrial estate)

\section{b) Tourist Attraction Development}

In order to develop a tourism destination, especially the attractiveness of the tourist is influenced by the development of thematic tourist spaces in a synergic, complementary and integrated arrangement of relations to encourage the growth of competitive tourism bintan district and tourism image bintan perceived as a safe and convenient destination and family oriented still needs to be upgraded and strengthened through the development of attraction, landscape setting, accessibility development, facilities and adequate infrastructure. For that need a strategic development of tourist attraction that must be made so that tourism in bintan can increase the tourists both foreign and domestic wisatwan. The direction of development policy mentioned above will be realized through strategy:

a) Pioneering the development of nature-based tourism (marine and terrestrial), cultural, and special / conventions, incentives, exhibitions and events in regional tourism development areas (KPPD) and regional tourism strategic areas (KSPD) to encourage the growth of activities local tourism

b) Development of nature-based tourism (marine and terrestrial), cultural, and special / convention, incentive, exhibition, and event areas to improve product quality and competitiveness in attracting the interest and loyalty of existing market segments

c) Consolidation of nature-based tourism attraction (marine and terrestrial, cultural, and special / convention areas, incentives, exhibitions, and events to enhance product competitiveness in attracting tourist visits and wider market segments

d) Revitalization of nature-based tourism attraction (marine and terrestrial, cultural, and special / convention areas, incentives, exhibitions, and events) in order to improve the quality, sustainability and competitiveness of products

c) Development of Accessibility And / or Tourism Transportation

Transportation system support including transportation routes or routes, terminal facilities, airports, ports and other transportation is essential to the development of tourism itself. In bintan itself has available transportation channels both land, sea and air. Sea transportation routes owned by island 3 bintan passenger port. Not only that, there are also sea lanes that access road through the path of neighboring countries such as sea stulang port, Malaysia. Not only that to go to the island bintan can also be accessed through the air, through the airport hang nadim chest in batam and Raja Haji Fisabilillah airport in tanjungpinang.

However, for the development and consolidation of transportation networks and infrastructure in support of tourist movement and tourism development, it is necessary to have policy directions that are poured in through strategies such as:

a) Development and consolidation of land transportation and infrastructure network, ferry transportation, sea transportation and air transportation in strengthening connectivity between regional and / or national tourism gateways with attraction locations and tourist centers

b) Development and Improvement of transportation infrastructure that supports the convenience of travel to destinations and tourist movements in Bintan

c) Development and stabilization of the availability, capacity, security and comfort of modes of transportation in improving accessibility and movement of tourists

d) Construction of public infrastructure, public facilities, and tourism facilities

Public utilities such as electricity, water and telecommunications are one of the things that is needed in the development of tourism in a tourist destination. The need for public infrastructure is needed by visiting tourists. Bintan as a tourist destination is also in desperate need of support it in the development of its territory.Namun currently suplay from PDAM Tirta Kepri and PLN still can not meet the needs of the people of Bintan.

Electricity in two areas of Bintan Island, Bintan and Tanjungpinang are never separated from the dead-living case and the rotating blackouts due to lack of power. PLTU Galang Batang that provides 2x15 MW power supply still can not meet the electricity needs of the people of Bintan, until there is an Batam-Bintan electricity interconnection plan to connect Batam's power source to Bintan in an effort to meet the electricity needs of Bintan people. So even with the problem of clean water, PDAM Tirta Kepri still can not meet the needs of customers. In the dry season people are still difficulty in getting clean water. 
- The direction of development policy mentioned above will be realized through strategy:

a) Preparation and Improvement of Public Infrastructure (electricity and lighting network, water supply network, sewerage system) in Bintan

b) Development of Telecommunication and Informatics Infrastructure to Support Tourism Development in Bintan

c) Increased new land opening for investors to build public infrastructure, public facilities, and faspar

e) Community Empowerment through Tourism

Tourism management should use the concept of community-based tourism development through empowerment programs. Community empowerment is a deliberate effort to facilitate local communities in planning, deciding and managing their local resources through collective action and networking so that they ultimately have economic, ecological and social capabilities and independence. In a broader sense, community empowerment is a facilitation process to encourage people to be able to position themselves proportionally and become key players in utilizing their strategic environment to achieve sustainable prosperity in the long term.

The Community Empowerment of Bintan Still Needs To Be Improved, Especially Local Society Awareness Will Benefit Development Tourism Far Away, Tourism Also Expected Can Provide Opportunity And Access To Local Community To Develop Tourism Supporting Enterprises Such As Handicraft Shop, Souvenir Shop, Warung Makan, And Lain -Other For Local People Get Better Economic Benefits And Provided Directly From Travelers To Improve their welfare and standard of living. Community empowerment through tourism can be realized through strategy:

1. Increasing community participation in tourism development in Bintan

2. Inventory and mapping of potential and local capacity building needs in developing tourism

3. Developing productive businesses in the field of tourism to increase local resources in Bintan

4. Develop the value chain of community effort in the field of tourism in Binta

\section{f) Development of tourism investment}

Efforts to increase investment can be realized through policies not only for upstream and downstream industries. Investors also feel new opportunities in the tourism sector. The development of an investment climate that still needs to be improved, especially about the ease of regulation and security of investing in bintan and the need for Increased investment incentives in the field of tourism in accordance with legislation. For that as for the strategy in the development of investment in tourism as follows:

a) Increase gradual tax relief for investment of Foreign Investment in tourism sector b) Improving the improvement of tax services for investment Foreign Investment in the tourism sector

c) Developing Debirocratization of investment in tourism

d) Develop Deregulation of regulations that impede licensing

e) Develop information on investment opportunities in tourism areas

f) Increasing the promotion of Bintan's investment in tourism in Indonesia and abroad

\section{TOURISM MARKETING}

a) Development Of The Tourist Market

Tourism marketing is an effort to look beyond the needs of the tourist market and the impacts of environmental changes on destinations. It can also be interpreted that the orientation of tourism marketing is an effort to respond to a highly competitive environment and to accommodate the advantages of the capacity possessed by a destination to meet various types and levels of demand of the tourist market. For that need to develop the tourist market to bintan by making a strategy such as:

a) Intensification of marketing and promotion programs in key markets

b) Promotion in potential markets in Europe

c) Development of co-marketing with travel related industries that sell outbound packages to Bintan

d) Developing and strengthening market research for key markets and potential markets

e) Promotion and Publication For Group of Interest Special Segments

\section{b) Development Of Tourism Image}

Branding of tourism bintan (breathtaking journey) needs to be balanced with the development of more creative and innovative products to strengthen the positioning bintan, in order to compete with batam and has a superior character. Tourists provide "different" tourism imaging between bintan and batam.Bintan more reflects the character: safe, special interest, high quality, family oriented holiday, so it needs to be built imaging and jabaran relevant tourism products. The dynamics of the increasingly critical (segmented) market and segmentation need to be anticipated with new product innovations, as well as the development of more diverse and effective marketing communications media. Therefore, it is necessary to strengthen the strategy to further develop tourism image of bintan. The strategy is like:

a) Marketing on Thematic Destinations For Mass Tourism Segment (Domestic): Bintan Culture Paradise, Bintan Seafood Paradise, Bintan Souvenir Paradise, Bintan Rest Area, Waterboom

b) Publications in order to Improve Awareness: Conscious Tourism

c) Providing Special Incentives for domestic tourist market 
d) Intensifkasi Publication and Promotion by Utilizing Brand "Bintan Breath Taking Journey"

e) Media Campaign As Strategy Establish Positioning Bintan As Tourism Destination Specifk.

c) Development of tourism marketing partnerships

Tourism marketing partners can be supported by the technology to promote it. Not only that it is necessary also the cooperation associated with the promotion and marketing of tourism abroad and create tour packages. For that we need a strategy to develop tourism marketing partnerships bintan such as:

a) Intensifkasi Publication and Promotion by Utilizing Brand "Bintan Breath Taking Journey"

b) Regional Tourism Marketing Development

\section{TOURISM INDUSTRY}

\section{a) Strengthening Tourism Industry Structure}

What is meant by the tourism industry structure is the function, hierarchy and relationships within the collection of tourism businesses that are accommodated by professional associations that coordinate and synergize together to improve the competitiveness of tourism in bintan. For that need a strategy for the tourism industry in bintan more focused and growing. The strategy is Facilitating the Establishment of Tourism Industry Organization in Bintan Regency

\section{b) Increased Competitiveness of Tourism Products}

Referred to as understanding the competitiveness of tourism products in this case includes the quality of goods and services capable of superior value by tourists, as measured through certification, standardization, competitive human resources. For that we need a strategy to improve product competitiveness in bintan more focused and growing. The strategy is to improve the Quality and Diversity of Tourism Products Products in Bintan Regency

\section{c) Development of environmental responsibility}

The meaning of environmental responsibility is the obligation of business operators based on the principles of environmental and cultural preservation. In the development of tourism will cause damage to the environment, for it needs a strategy that needs to be made for the development of tourism to the environment is maintained. The strategy is:

1. Development of environmentally conscious tourism in Bintan Regency

2. Developing Tourism Business management that care about environmental conservation and culture of Bintan Regency

\section{INSTITUTIONAL INSTITUTIONS}

a) Development of Tourism Organization

Tourism is a sector that has a high intensity of relationships and linkages with other sectors or sectors both cross-sectoral and cross-regional (cantonal). The existence of an organization engaged in tourism can essentially be at the community level, private / industrial or business, as well as at the government level in order to facilitate the management and accelerate the achievement of the goals of tourism development itself. Therefore, to develop tourism in bintan, it is necessary in the form of tourism organization which includes government organization, local government organization, private organization / industry and organization from society. Development of tourism organization can be realized through strategy:

a) Strengthening the role of the private sector in increasing the acceleration of development Tourism through Public Private Partnership (PPP) / Good Tourism Governance

b) Develop and revitalize community organizations in tourism

c) Improving government services to private and public

d) Restructuring and Repositioning Tourism Organization at the District Level

e) Optimizing Coordination and Synergy among Stakeholders

f) Improve synchronization and coordination of tourism activities between government, private, and community

\section{b) Tourism Human Resource Development}

The potential embodied in human beings to realize their role as adaptive and transformative social beings capable of managing themselves and all the potential contained in nature towards the achievement of the welfare of life in a balanced and sustainable order in the field of tourism, for the development of tourism human resources can include government institutions atay local governments, private institutions, and communities. the development will then be realized through the strategy:

a) Optimizing the quality and capacity of human resources of Bintan Regency Government Institution

b) Optimizing HR Tourism In Bintan

c) Quality acceleration of tourism educators

d) Develop cooperation between educational institutions and the tourism industry

e) Increasing the role of people around tourism destinations

\section{CONCLUSION}

Higher progress and prosperity has made tourism a central part of human needs or lifestyle, and drives millions of people to know nature and culture to parts of the world.

Tourism for many regions in Indonesia is very reliable as a leading sector with the ability to support the local economy. As one of the development sectors, tourism becomes a resource that can support the improvement of local potential, so as to narrow the gap that may occur with other regions that have similar resources.

Bintan Regency is one of 511 Kabupatendi territory of the Unitary State of the Republic of Indonesia. 
Geographically, Bintan regency is located between O'6'17 "North Latitude - 1'34'52" North Latitude and 104'12'47 "East Longitude is west - 108'2'27" East Longitude to the East. The total area of Bintan Regency reaches $88,038.54 \mathrm{~km} 2$, but the land area is only $2.21 \%, 1,946.13 \mathrm{~km} 2$ only. The widest sub district is Gunung Kijang sub district with an area of 503,12 $\mathrm{km} 2$ and the smallest is Tambelan which is 169,42 square kilometers.

Objects and attractions in the district of Bintan very much and varied. Some are excellent attractions, such as Lagoi and Trikora Beach and there are objects that are being developed or undeveloped but also visited by tourists.

The challenges of tourism development in Bintan Regency include:

A. External Environment

1) Tourism Destination

a) Global Warming and Its Impact on Tourism Destination

b) Globalization and Its Impact on Tourism Destination Development Management

c) Bintan Has a Highly Strategic Linkage with Singapore in Tourism Development

2) Tourism marketing

d) Environmentally Friendly Tourism Marketing (Responsible Tourism Marketing)

e) Smart consumen

f) An increasingly fragmented market segment which can not equalize the treatment for all market segments

3) Tourism Industry

g) The Millennium Development Goals

h) Global Code of Ethics Tourism (Global Code of Ethics Tourism)

i) International Trade Policy

j) Concept and Scope of International Services Trade in GATS

k) Indonesian Liberalization Commitment in Tourism Business Transaction

1) Tourism Competitiveness Index

4) Tourism Institution

m) The implementation of regional autonomy in regency / municipality can be an opportunity for the regions to utilize it.

n) Not yet strong macro institutional performance at the national level

o) A container for tourism businesses in Bintan is required

p) The enactment of the ASEAN Free Market - MEA 2015, requires Bintan ready to face tourism human resources from other countries

B. Internal Environment
a) Tourism Destination
b) Tourism Marketing
c) Tourism Industry
d) Institutional and Human Resources Tourisml
e) The principles used in the preparation of norms are:

a. Sustainable Tourism Development and Sustainable Tourism Development

b. Ecological Conservation

c. Pro Poor, Pro Job, Pro Growth, Pro Environment

d. Development of Community-Based Tourism (Community-Based Tourism Development)

e. Global Tourism Competitiveness (Global Travel and Tourism Competitiveness)

f. Tourism Development Based on Good Governance (Good Tourism Governance)

g. Integration of the Development of CrossSectoral, Cross-Local, and Cross-Border Tourism

\section{REFERENCES}

[1] Akil, S. 2007. Artikel Implementasi Kebijakan Sektoral dalam Pengembangan Pariwisata Berkelanjutan dari Perspektif Penataan Ruang. Depbudpar: Jakarta.

[2] Alastair M. H. 1989. Hospitality and Travel Marketing. Delmar Publisher: New YorkBater, J. et al. (2001). Planning for Local Level: Sustainable Tourism Development, Canadian Universities Consortium: Urban Environmental Management Project Training \& Technology Transfer Program, Canadian International Development Agency (CIDA)

[3] Bateson E. G. John, Hottman D.K. (1999). Managing Services Marketing, The Dryden Press: Harcourt Brace College Publishers.

[4] Blanke, J. and Chiesa, T. (2008). World Economic Forum.Switzerland, 2008. The Travel \& Tourism Competitiveness Report 2008. Balancing Economic Development and Environmental Sustainability. WEF: Switzerland.

[5] Briggs, S. 1997. Successful Tourism Marketing: A Practical Handbook, Kogan Page Lt.d. : London.

[6] Boxwell, Robert J., Jr. 1994. Benchmarking for Competitive Advantage, McGraw-Hill, Inc: New York.

[7] Departemen Kebudayaan dan Pariwisata. 2002. Buku Cetak Biru Pemasaran Pariwisata Indonesia. Depbupar: Jakarta.

[8] Departemen Kebudayaan dan Pariwisata. 2005. Rencana Strategis Pembangunan Kebudayaan dan Pariwisata Nasional 2005 - 2009. Departemen Kebudayaan dan Pariwisata RI: Jakarta.

[9] Departemen Kebudayaan dan Pariwisata. 2006. Dampak Ekonomi Pariwisata Tahun 2005. Neraca Satelit Pariwisata Nasional Tahun 2006. Departemen Kebudayaan dan Pariwisata: Jakarta

[10] Gunn, Clare A. 1994. Tourism Planning. Basics Concepts Cases. Third Edition. Taylor\&Francis: Washington D.C.

[11] Hawkins, donald E. 1980. Tourism marketing and management issues, Washington

[12] Lombote, Stefanus. (2015). Peranan Pemerintah Daerah Dalam Mengembangkan Objek Wisata Pulau Mahoro Kabupaten Sitoru. E-Journal. Universitas Sam Ratulangi.

[13] Pitana, I Gde, dkk. (2009). Pengantar Ilmu Pariwisata. Yogyakarta: C.V ANDI OFFSET.

[14] Sunaryo, Bambang. (2013). Kebijakan Pembangunan Destinasi Pariwisata Konsep Dan Aplikasinya Diindonesia. Yogyakarta: Gava Media. 